\title{
FARMING FOR THE PRODUCTION OF STORE STOCK
}

\author{
G. REED \\ Farmer, Piopto
}

\section{INTRODUCTION}

MY PROPERTY consists of 301 ha of hill country, one-third steep, two-thirds medium, sited $18 \mathrm{~km}$ west of Piopio in the rain shadow of the Pomerangi Ranges, with an annual rainfall of about $2540 \mathrm{~mm}$. It is all in grass except 16 ha of rocks and patches of scenic bush, and is well fenced with 22 main paddocks and 8 small holding paddocks. All paddocks have adequate natural water and access to the farm is very good because of county roads radiating from the woolshed. This is a very real advantage in one-man farming of hill country. The longest drive for a mob of ewes and lambs would usually be less than one hour, depending on variables such as dog behaviour.

Winters are not particularly severe by King Country standards. A good winter creep of grass is assured by the sheltered nature of the valley setting, and as the result of a consistent superphosphete application over the past 15 years.

Supplementary feeding is kept minimal, the breeding herd getting hay for one month only before calving and the young cattle confined to two months of hay feeding. Other than the annual purchase of 1000 bales of hay, feeding is all grass.

The soils are sedimentary. On the steeper slopes mudstones overlie a very free-draining rubble subsoil. On the easier areas Mairoa ash has settled, giving better moisture retention, but unfortunately also inherently high phosphate fixation.

\section{HISTORY}

A verv brief history of this area goes back to 1903 and the start of felling of the dense native bush cover. Burning and oversowing by hand followed and dairying prospered for the first ten to twelve years while the potash remained from the burns.

Then tragically, as this fertility ran out, much of the land reverted to fern, secondary growth, and ragwort. World War I followed, drawing away many of the young men and by 1922 some settlers had abandoned their hard-won farms. The long, 
slow recovery started about 1930 with the initiation of the Land Development Scheme, bringing with it amalgamation of dairy units and the start of topdressing. Rapid improvement to its present state came with aerial topdressing around 1947.

\section{PURChASE AND DEVELOPMENT}

When I bought the property in 1965 it was developed but understocked, unimproved grasses were predominant (Yorkshire fog the commonest), clover was sparse and not at all vigorous. However, clovers have not been oversown as these have increased with the decline of unimproved species because of heavier stocking rates.

Although limited areas can be cultivated, I see no advantage in disturbing the topsoil. For example, on one area, cultivated before my time, much of the topsoil was washed off, Californian thistles appeared and were bad for years, and it is only now settling down to grow good pasture.

Financing of the property in 1965 was on $25 \%$ equity and I was fortunate to have two good market seasons before the 1967 recession. The four years that followed necessitated tip-toeing a narrow financial path and no doubt those years have had a very strong bearing on the low cost-low labour input system I have adopted. With a $\$ 2$ per stock unit debt servicing figure, there has been little room for error, major policy changes, or marginally-profitable development.

\section{StOCK NUMBERS}

Ewe numbers wintered have varied betwen 1550 and 1970, ewe hoggets between 700 and 850 , ram hcvggets up to 160 , and 40 rams. Cattle numbers have been relatively static at 100 breeding cow's wintered and 115 replacements, half yearling, half two-year-old. The present winter carrying is 3170 stock units or 11 units/ha. There is no question it could carry more and did so before two recent droughts. However, this rate has enabled me to calve two-year heifers successfully and to have my livestock in a condition I can take pleasure in. The ratio of cattle to sheep is 1 to 10 .

\section{BASIC OBJECTIVES OF MANAGEMENT}

My basic management objective can be summed up simply as: "Maximum returns from optimum numbers of breeding stock with lowest feasible labour input". 
I have adhered to breeding stock, ewes and cows, with no carryover of male progeny other than ram Iambs. However, I always endeavour to take all female progeny through to maturity and sell the surplus.

My fundamental aim has always been to keep management as simple and streamlined as possible. To 'achieve this I have kept to one breed of sheep, Romney, and one of cattle, Angus. Mob numbers are kept minimal over winter, involving only three mobs of sheep-mixed-age ewes, two-tooth ewes and hoggets, and two mobs of oattle mixed-age cows, with weaners and twentymonth cattle running together. I have [avoided buying stock as it requires time and special skills.

\section{STOCK POLICIES}

I have fattened all wether lambs in four out of the last eight years. Last summer they averaged $14.3 \mathrm{~kg}$ in February. In future, unless we have prolific January pasture growth, I intend to sell the lambs earlier as stores for I believe the grass can be better utilized on capital stock. Also the labour input in fattening lambs on these hills is high. This 'decision to fatten or sell I find easier to make after being away for two weeks at the beach over Christmas. I plan my work to make this break possible and look on it as an essential part of my programme.

In an attempt to lift the performance of my ewes six years ago I started my own ram-breeding flock. To qualify as probationary members, twotooth ewes that successfully weaned two reasonable lambs unaided were identified and entered and were required to raise at least a further three lambs in the next two seasons or face expulsion. I went to considerable lengths to buy sires with as long a history of twinning and troublefree lambing as possible. I also required them to have a hogget-fleece weight well above average for the parent stud. Twinning repeatability is showing up quite strongly in the flock of 250 recorded ewes and last season they docked $122.5 \%$ of lambs. Fleece weights of the hoggets also look promising. Last season 128 averaged $0.56 \mathrm{~kg} / \mathrm{month}$ from lamb shearing in December to winterhogget shearing in August. I have found this very encouraging as I regard fleece weight of more importance than style in a second-shear flock where carpets are the end use.

Unfortunately, the heritability of twinning is not high. Under intensive selection, I understand one could only expect about 1 to $3 \%$ per annum improvement. However, I am now sure that the qualities of alertness, open faces and longer legs are 
rapidiy becoming apparent from using these easy-care rams that have been subjected to environmental selection pressure. These attributes should lead to improved lamb survival, a feature that has let the Romney breed down, and has contributed to widespread criticism of the performance of many Romney sheep on North Island hill country.

\section{SHEEP MANAGEMENT}

Again, simplicity has been my aim in the feeding of livestock. 1 have stayed clear of labour-demanding techniques such as intensive rotational grazing and break-feeding of pasture.

Ewes are set-stocked at lambing at $11 /$ ha and hoggets at 15/ha on the less accessible paddocks. Lambing paddocks are generally fairly bare when the ewes go in a week before lambing. I have had no metabolic problems to date. The two-tooth ewes are shepherded twice a day, any that have to be handled being marked for culling. I aim for 'any two-tooth finding its way into the mixed-age flock to have a clean maternity record.

I did not shepherd the mixed-age flock in 1972. Twelve ewes died out of 1100 , no bearing trouble was experienced, and lamb mortality did not appear high; however, twinning was down because of a dry preceding 'autumn. Ninety-two percent. of lambs were docked from the entire flock. Again in 1973 the mixed-age flock was unshapherded and total lambing percentage expressed as lambs docked from all ewes mated was 95.

I am tending to subscribe to the thought that a man and a dog moving through lambing ewes cause as much disturbance as a rook thrown into a millpond and perhaps are the authors of many lambing problems. I would qualify this statement by emphasizing that these ewes are well grown and are not overfed.

The ewes are shorn in mid-October. This practice keeps dagging to a minimum and enables the autumn shearing to be done before the rams go out, thus avoiding tup crutching. The timing of these two shearings enables two arduous jobs to be cut out of the seasonal programme. All lambs are weaned and shorn early in December. I adhere to this programme as it is generally only after weaning, when the ewes are tightened up, that I have any surplus grass.

After weaning, I endeavour to fed the ewes as well as possible, after preference has been given to young stock and cows 
and calves. The ewes are run on blocks of about three paddocks at around 25/ha and as feed runs out it simply requires the addition of a further paddock to spread them at around $16 / \mathrm{ha}$. In July a conscious endeavour is made to lift their rations by moving them on to the hogget paddocks and tighten up the hoggets.

I have never saved autumn grass for the flock but rely on winter growth to get 'them through. I give as much preference to the rising two-tooth ewes over the summer as to the ewe lambs.

Lambs are drenched every five weeks throughout summer and autumn and I try not to exceed 12.5 /ha on a block-grazing system, moving them on to controlled saved grass when possible.

\section{CATTLE MANAGEMENT}

I have always worked on the principle of never running cattle with sheep when there is competition, as sheep will win hands down.

From the time the calves are weaned in late March, the herd is used for cleaning up, though rarely is there much rank pasture, save perhaps on some shady faces. Then the cows are run separately from the ewes on restricted feed to mid-July. They then get one bale of hay to seven cows and very little else. This lasts for four weeks until the first calf is born in mid-August when the entire mixed-age herd goes on to an 18 ha paddock of wintersaved grass shut up since early June. I do not go through them again.

My property had a bad 'history of metabolic trouble in cows and I chose this paddock as it has a bush boundary and had been rather more laxly grazed. I have kept it that way with a high proportion of unimproved grasses and usually escape with only one loss. This 18 ha paddock carries them at nearly 4/ha for about seven weeks to mid-October when I can 'tighten up the hoggets, and cut out 35 cows land calves and move them on to a fresh-growth hogget paddock and hope that grass staggers is over for the season.

Less provision is needed for the three-year-old heifers. They go on to a fresh paddock after hay feeding is over at less than $2.5 /$ ha and calve down without loss.

The 100-odd yearling land two-year-old heifers spend all winter from May on a 28 ha block with two months of hay feeding and the mated two-year-old heifers do not start to calve until early October. Calving is restricted to four weeks and it is then my practice to take out the yearlings and feed the two-year-olds 
ad lib. These yearlings are only introduced to the sheep paddocks when patch grazing becomes (apparent.

All cows are pregnancy-tested in April and calving is usually 93\% with perhaps two dead calves and apparently about five cows slipping their calf though I rarely see them.

\section{PROBLEMS}

Expenditure on weed control is very low. Blackberry was getting a hold but goats have kept it under control. They have considerable value on broken country in limited numbers and I regard them as members of my staff.

Yorkshire fog was my worst weed when the farm was taken over understocked. This has largely gone with heavier stocking and topdressing at $375 \mathrm{~kg} / \mathrm{ha}$ of superphosphate. But with the departure of Yorkshire fog an insidious and unspectacular weed crept in which I consider the worst weed in this district hydrocatyle. With its very close ground cover that never comes into the limelight with flowers or seeds, it has managed to cover large 'areas, particularly under prolonged set-stoicking. It is now less of a problem, perhaps, because, now that unimproved grasses are in a minority, I no longer need to graze blocks hard for the prolonged periods that seem to predispose this weed.

Regarding labour, with this simplified system I can handle the farm very comfortably with the use of occasional casual labour and never fall behind with seasonal stock work.

\section{PHILOSOPHY}

Perhaps being a first-generation farmer with no farming background has played a large part in my objectively treating this venture first and foremost as a business. I was very aware of the dangers of a one-man farmer becoming a slave to his enterprise. I put considerable value on my free time and endeavour to keep to a forty-hour week when possible.

From time to time I have requested my accountant to prepare a statement of Return-on-Equity Capital. Had I felt this return was too low, I would have looked for an alternative investment. Return on equity capital in 1969 was $9.7 \%$; in 1973, 22.7\%. This laiest figure has delayed my search for a sun-soaked coconut plantation on a coral island just off Tahiti.

I will conclude by making the prediction that the future looks bright enough for the low-equity farmer in this district provided: 
(1) His borrowing is long term.

(2) Any major development programme shows a reasonably quick return.

(3) That not more than one of his three main sources of income, is depressed at any one time.

(4) And finally, and perhaps most important - that he treats farming as a business, maintaining a professional approach to his problems, financial or otherwise, fully realizing that the high cost of getting started must be justified by maximum return from his investment. It should also be justified by the pleasure, regardless of financial gain, that can be had from this form of businses. 